\title{
ChemComm
}

\section{Uranium(III) and thorium(Iv) alkyl complexes as potential starting materials $\uparrow$}

Cite this: Chem. Commun., 2016 52,14373

Received 7th October 2016, Accepted 10th November 2016

DOI: $10.1039 / c 6 c c 08105 c$

www.rsc.org/chemcomm

\author{
Andrew C. Behrle, $\ddagger^{\mathrm{a}}$ Alexander J. Myers,$\neq^{\mathrm{a}}$ Pokpong Rungthanaphatsophon, ${ }^{\mathrm{a}}$ \\ Wayne W. Lukens, ${ }^{b}$ Charles L. Barnes ${ }^{a}$ and Justin R. Walensky*a
}

The synthesis and characterisation of a rare $\mathrm{U}(\mathrm{III})$ alkyl complex, $\mathrm{U}\left[\eta^{4}-\mathrm{Me}_{2} \mathrm{NC}(\mathrm{H}) \mathrm{C}_{6} \mathrm{H}_{5}\right]_{3}$, using the dimethylbenzylamine (DMBA) ligand has been accomplished. While attempting to prepare the $\mathrm{U}$ (Iv) compound, reduction to the U(III) complex occurred. In the analogous Th(Iv) system, $\mathrm{C}-\mathrm{H}$ bond activation of a methyl group of one dimethylamine was observed yielding $\operatorname{Th}\left[\eta^{4}-\mathrm{Me}_{2} \mathrm{NC}(\mathrm{H}) \mathrm{C}_{6} \mathrm{H}_{5}\right]_{2}\left[\eta^{5}-\right.$ $\left.\left(\mathrm{CH}_{2}\right) \mathrm{MeNC}(\mathrm{H}) \mathrm{C}_{6} \mathrm{H}_{5}\right]$ with a dianionic DMBA ligand. The utility of these complexes as starting materials has been analyzed using a bulky dithiocarboxylate ligand to yield tetravalent actinide species.

During the Manhattan project, actinide alkyl complexes were desirable for their potential as volatile compounds for separations, especially uranium enrichment. ${ }^{1}$ More recently, organoactinide chemistry has experienced increased attention as exemplified by the Hayton and Bart groups. For example, Hayton has reported homoleptic U(Iv), ${ }^{2} \mathrm{U}(\mathrm{v})$, and $\mathrm{U}(\mathrm{vI})$ alkyl $^{3}$ complexes as well as Th(Iv) alkyl $^{1}$ and aryl $^{4}$ complexes while Bart has produced a series of U(Iv) benzyl compounds. ${ }^{5,6}$ Nevertheless, Th(Iv) and U(III) alkyl complexes $^{7-11}$ remain scarce.

Recently, the Hayton group has used the lithium salt of dimethylbenzylamine (DMBA) to synthesize Th(Iv) and U(Iv) complexes. ${ }^{12,13}$ The lithiation of dimethylbenzylamine produces an ortho-metalated phenyl anion. This salt may be converted to the benzyl anion by reaction with potassium tert-butoxide, ${ }^{14,15}$ which is accompanied by a proton migration from the alpha-position of the benzyl methylene to the ortho-position of the phenyl. The only known complexes using this ligand transfer agent as starting material are a zirconium complex ${ }^{16}$ as well as most of the lanthanide series. ${ }^{15}$ Since the Ln(III) complexes are stabilized by this ligand, we surmised that $\mathrm{U}(\mathrm{III})$ would be stabilized in a similar fashion.

\footnotetext{
${ }^{a}$ Department of Chemistry, University of Missouri, Columbia, MO 65211, USA. E-mail: Walenskyj@missouri.edu

${ }^{b}$ Chemical Sciences Division, Lawrence Berkeley National Laboratory, Berkeley, California 94720, USA

$\dagger$ Electronic supplementary information (ESI) available. CCDC 1507960-1507963. For ESI and crystallographic data in CIF or other electronic format see DOI: $10.1039 / \mathrm{c} 6 \mathrm{cc} 08105 \mathrm{c}$

\$ Authors contributed equally to this work
}
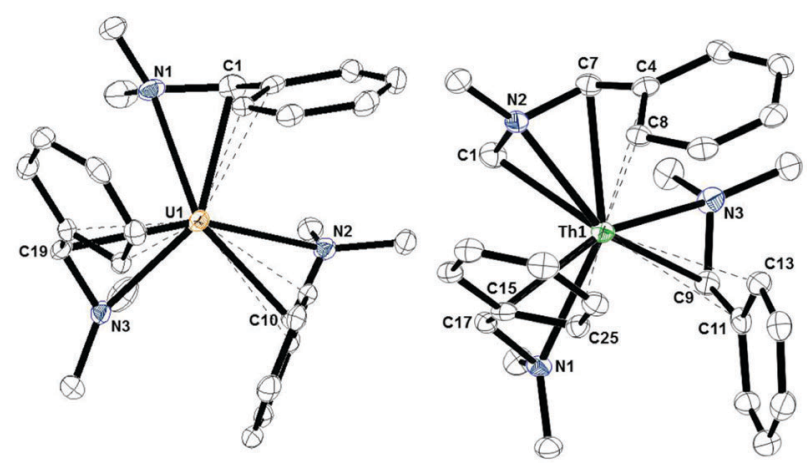

Fig. 1 Thermal ellipsoid plot of 1 (left) and 2 (right) shown at the 50\% probability level. The hydrogen atoms have been omitted for clarity.

Reaction of $\mathrm{UI}_{3}(\mathrm{THF})_{4}$ with three equivalents of $\mathrm{K}\left[\mathrm{Me}_{2} \mathrm{NC}(\mathrm{H})\right.$ $\left.\mathrm{C}_{6} \mathrm{H}_{5}\right]$ in $\mathrm{Et}_{2} \mathrm{O}$ for $3 \mathrm{~h}$ at $-25{ }^{\circ} \mathrm{C}$, eqn (1), results in a dark coloured solution. X-ray quality crystals were grown from a saturated toluene solution at $-25{ }^{\circ} \mathrm{C}$, and diffraction revealed the $\mathrm{U}$ (III) complex, $\mathrm{U}\left[\eta^{4}-\mathrm{Me}_{2} \mathrm{NC}(\mathrm{H}) \mathrm{C}_{6} \mathrm{H}_{5}\right]_{3}, \mathbf{1}$, Fig. 1. Reaction with $\mathrm{UCl}_{4}$ also produced 1 along with half an equivalent of 1,2-bis(dimethylamino)-1,2-diphenylethane. The ${ }^{1} \mathrm{H}$ NMR spectrum of $\mathbf{1}$ is fluxional at room temperature, but cooling to $-78{ }^{\circ} \mathrm{C}$ made the spectrum assignable. The ${ }^{1} \mathrm{H}$ NMR spectrum is paramagnetically shifted, and the amine methyl resonances are inequivalent at $47 \mathrm{ppm}$ and $-71 \mathrm{ppm}$. The methine proton is located at $-94 \mathrm{ppm}$. Complex 1 is thermally unstable above room temperature but stable when stored cold in the solid-state. As mentioned previously, this compound represents a rare U(III) alkyl complex.

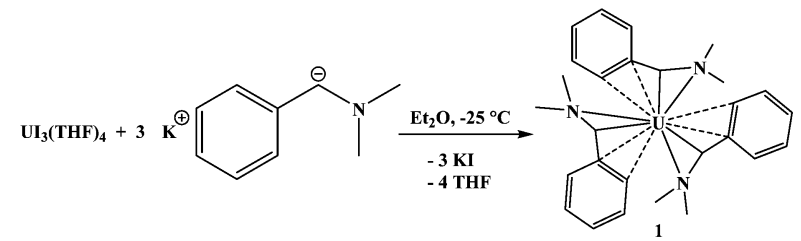




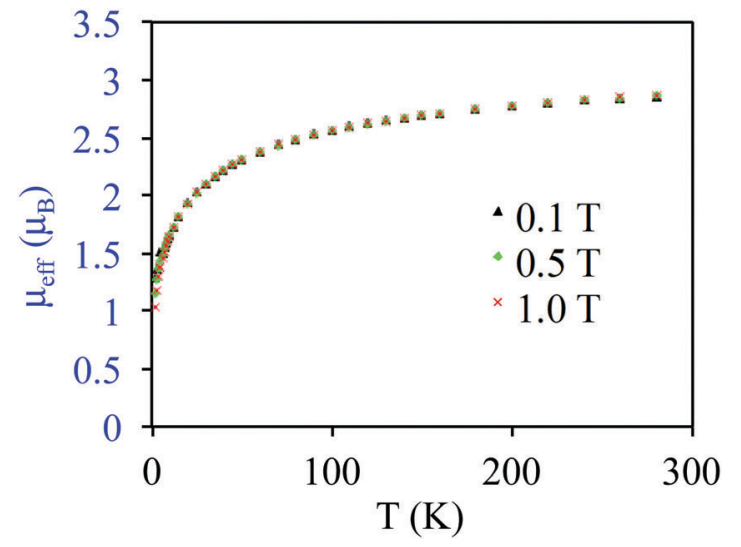

Fig. 2 Variable temperature magnetic moment of 1.

The U- $\mathrm{C}_{\mathrm{ipso}}$ distances are 2.766(3), 2.784(3), and 2.804(3) $\AA$ while the $\mathrm{U}-\mathrm{C}_{\text {ortho }}$ distances are 2.818(3), 2.813(3), and 2.816(3) $\AA$. These distances are far shorter than the closest U-C interactions in $\mathrm{U}\left[\mathrm{CH}\left(\mathrm{SiMe}_{3}\right)_{2}\right]_{3}$ but are similar to those found in $\left[\mathrm{U}(\mathrm{dddt})_{3}\right]^{2-}$, dddt $=$ 5,6-dihydro-1,4-dithiine-2,3-dithiolate. ${ }^{17}$ Therefore, the best description of the coordination of the DMBA ligand to uranium is $\eta^{4}-(N, C, C, C)$ instead of the $\kappa^{2}-(N, C)$ form resulting from the lithium salt. The uranium-methine carbon bond distances of

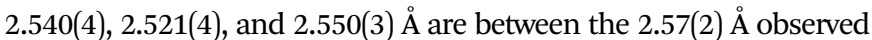
in $\mathrm{Tp}_{2}^{*} \mathrm{U}\left(\mathrm{CH}_{2} \mathrm{C}_{6} \mathrm{H}_{5}\right), \mathrm{Tp}^{*}=$ hydrotris(3,5-dimethylpyrazolyl)borate, and $2.48(2) \AA$ in $\mathrm{U}\left[\mathrm{CH}\left(\mathrm{SiMe}_{3}\right)_{2}\right]_{3}$.

The magnetization of $\mathbf{1}$ was studied by variable temperature and variable field experiments. The effective magnetic moment of 1 is shown in Fig. 2. Under Russell-Saunders coupling, U(III) has a ${ }^{4} \mathrm{I}_{9 / 2}$ ground multiplet, which is split by the ligand field into substates characterized by $m_{\mathrm{J}}$. The measured ground state moment of 1 is $1.11 \mu_{\mathrm{B}}$, which is in excellent agreement with that of the $m_{\mathrm{J}}=3 / 2$ substate $\left(1.09 \mu_{\mathrm{B}}\right)$. Assignment of this ground state to $\mathbf{1}$ is supported by a failure to observe an EPR spectrum at $2 \mathrm{~K}$ as the $m_{\mathrm{J}}=3 / 2$ substate is not EPR active. The first excited state of 1 is $\sim 100 \mathrm{~cm}^{-1}$ above the ground state as determined from the temperature at which the plot of $\chi T v s . T$ deviates from linearity. Although U(III) complexes frequently exhibit single molecule magnet (SMM) behaviour, ${ }^{18} 1$ does not display a hysteresis in the magnetization $v s$. field measurements at $2 \mathrm{~K}$. The lack of SSM behaviour is surprising given the $\sim 100 \mathrm{~cm}^{-1}$ energy of the first excited state. We believe the mechanism for relaxation is tunneling due to dipole-dipole coupling in analogy to the behaviour of $\mathrm{U}\left(\mathrm{H}_{2} \mathrm{BPz}_{2}\right)_{3} \cdot{ }^{19}$ The $\mathrm{U}-\mathrm{U}$ distance in $\mathbf{1}$ is $8.0 \AA$, which is shorter than the $8.2 \AA$ distance in $\mathrm{U}\left(\mathrm{H}_{2} \mathrm{BPz}_{2}\right)_{3}$, which does not display SMM behaviour, and much shorter than that of $\mathrm{U}\left(\mathrm{Ph}_{2} \mathrm{BPz}_{2}\right)_{3}(10.8 \AA)$, which does display SMM behaviour. ${ }^{20}$

Thorium presented an interesting comparison since Th(III) is only accessible using strong reducing agents, ${ }^{21}$ and since all previously reported compounds of the DMBA ligand needed only three ligands to saturate the coordination sphere. The reaction of $\mathrm{ThCl}_{4}(\mathrm{DME})_{2}$ with four equivalents of $\mathrm{K}\left[\mathrm{Me}_{2} \mathrm{NC}(\mathrm{H}) \mathrm{C}_{6} \mathrm{H}_{5}\right]$ at $-78{ }^{\circ} \mathrm{C}$, eqn (2), produced an orange solution. The ${ }^{1} \mathrm{H}$ NMR spectrum revealed an asymmetric coordination environment as well as protonated ligand. Orange crystals suitable for X-ray diffraction analysis were obtained from a saturated toluene solution at $-25{ }^{\circ} \mathrm{C}$. The structure, Fig. 1 , is similar to previous complexes with three DMBA ligands; however, one of the methyl groups has undergone $\mathrm{C}-\mathrm{H}$ bond activation to afford a dianionic DMBA ligand, Th[$\left[\eta^{4}-\mathrm{Me}_{2} N C(\mathrm{H}) \mathrm{C}_{6} \mathrm{H}_{5}\right]_{2}\left[\eta^{5}-\left(\mathrm{CH}_{2}\right) \mathrm{MeNC}(\mathrm{H}) \mathrm{C}_{6} \mathrm{H}_{5}\right], 2$. Similar systems in which $\mathrm{U}(\mathrm{Iv})$ yields a $\mathrm{U}(\mathrm{III})$ product and $\mathrm{Th}$ (IV) results in $\mathrm{C}-\mathrm{H}$ bond activation have been observed previously. ${ }^{22,23}$

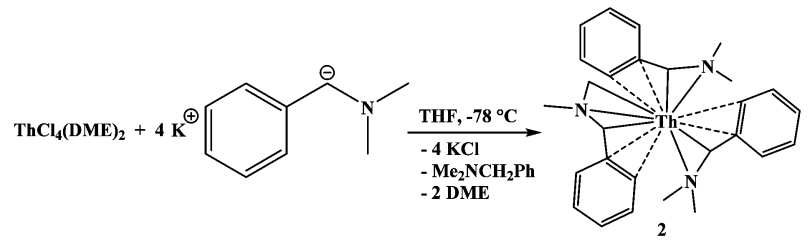

The Th1-C1, Th1-N2, Th1-C7, Th1-C4, and Th1-C8 bond distances are 2.545(4), 2.453(3), 2.578(4), 2.606(3), and 2.866(3) А, respectively, so the ligand with the $\mathrm{C}-\mathrm{H}$ bond activated methyl group is a dianionic, $\eta^{5}$-ligand. The $\mathrm{Th}-\mathrm{C}_{\text {methine }}$ bond distances in 2, 2.578(4), 2.608(4), and 2.620(3) $\AA$, are slightly longer than the Th- $\mathrm{C}_{\text {benzyl }}$ bond length of 2.551(7) $\AA$ in $\left(\mathrm{C}_{5} \mathrm{Me}_{5}\right)_{2} \mathrm{Th}\left(\mathrm{CH}_{2} \mathrm{C}_{6} \mathrm{H}_{5}\right)_{2} \cdot{ }^{24}$ However, the $\mathrm{Th}-\mathrm{C}_{\mathrm{ipso}}$ bond distances of $2.850(4), 2.908(4)$, and 2.851(4) A are significantly shorter than the Th- $\mathrm{C}_{\text {ipso }}$ bond distance of 2.979(6) $\AA$ in $\left(\mathrm{C}_{5} \mathrm{Me}_{5}\right)_{2} \mathrm{Th}\left(\mathrm{CH}_{2} \mathrm{C}_{6} \mathrm{H}_{5}\right)_{2}$, but are similar to the 2.700(8)2.842(4) Å observed for $\mathrm{U}-\mathrm{C}_{\text {ipso }}$ interactions in $\mathrm{U}\left(\mathrm{CH}_{2} \mathrm{C}_{6} \mathrm{H}_{4} \mathrm{R}\right)_{4}, \mathrm{R}=\mathrm{H}$, 2-p- ${ }^{\mathrm{i}} \mathrm{Pr} ; 2-p-{ }^{t} \mathrm{Bu} ; 2-m-\mathrm{OMe} ; 2-o$-picolyl, complexes, ${ }^{6}$ when the difference in ionic radii are taken into account.

To demonstrate the utility of $\mathbf{1}$ and $\mathbf{2}$ as potential starting materials for further substitution, both were treated with three and four equivalents of $\mathrm{HS}_{2} \mathrm{C}\left[2,6-(\mathrm{Mes})_{2} \mathrm{C}_{6} \mathrm{H}_{3}\right]$, Mes $=2,4,6$ $\mathrm{Me}_{3} \mathrm{C}_{6} \mathrm{H}_{2}$, eqn (3). In both cases, the product is a tetravalent species, $\mathrm{An}\left[\mathrm{S}_{2} \mathrm{C}\left(2,6-(\mathrm{Mes})_{2} \mathrm{C}_{6} \mathrm{H}_{3}\right)\right]_{4}(\mathrm{THF}), \mathrm{An}=\mathrm{U}, \mathbf{3}$; Th, 4, eqn (3). Both $\mathbf{3}$ and $\mathbf{4}$ were characterized by $\mathrm{X}$-ray crystallography and were found to be structurally analogous ( 3 is shown in Fig. 3). Both are nine-coordinate with eight sulfur atoms and one THF molecule completing the coordination sphere in a monocapped square antiprismatic geometry. It is surprising that both thorium(Iv) and uranium(Iv) are large enough to accommodate four ligands as well as a THF molecule since dithiocarbamate, ${ }^{25}$ dithiophosphinate $^{26}$ and dithiolene ${ }^{17}$ actinide(Iv) complexes are typically eight-coordinate. Our rationale for the presence of the THF molecule is that it may be bound to the metal center prior to or during the addition of the $\left[\mathrm{S}_{2} \mathrm{C}\left(2,6-(\mathrm{Mes})_{2} \mathrm{C}_{6} \mathrm{H}_{3}\right)\right]^{1-}$ ligands, and upon coordination of the dithiocarboxylate ligands, the THF is captured in the inner coordination sphere. The THF molecule cannot be removed by heat or vacuum. The space filling model of the compound is consistent with this explanation as is the observation that both complexes precipitate from the reaction mixture when the reaction is performed in THF. Another interesting feature of complexes $\mathbf{3}$ and $\mathbf{4}$ is that typically homoleptic sulfurbased complexes are not produced by protonation reactions. For example, reaction of $\left[\left\{\left(\mathrm{Me}_{3} \mathrm{Si}\right)_{2} \mathrm{~N}\right\}_{2} \mathrm{U}\left(\mathrm{CH}_{2} \mathrm{SiMe}_{2} \mathrm{NSiMe}_{3}\right)\right]$ with one equivalent of 2,6- $\mathrm{Me}_{2} \mathrm{C}_{6} \mathrm{H}_{3} \mathrm{SH}$ yields $\left[\left(\mathrm{Me}_{3} \mathrm{Si}\right)_{2} \mathrm{~N}\right]_{3} \mathrm{U}\left[\mathrm{S}\left(2,6-\mathrm{Me}_{2} \mathrm{C}_{6} \mathrm{H}_{3}\right)\right]$, but using four equivalents results in intractable products. ${ }^{27}$ In our case, reaction of 1 or 2 with four equivalents of $\mathrm{HS}_{2} \mathrm{C}[2,6$ (Mes) ${ }_{2} \mathrm{C}_{6} \mathrm{H}_{3}$ ] produced isolable compounds. Both compounds 


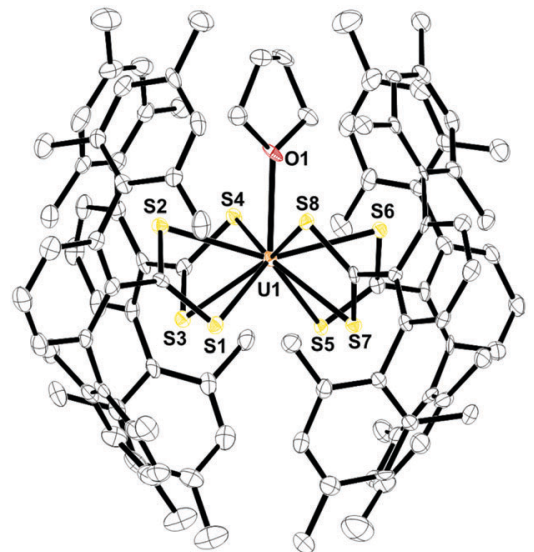

Fig. 3 Thermal ellipsoid plot of $\mathbf{3}$ shown at the $50 \%$ probability level. The hydrogen atoms have been omitted for clarity.

are viable starting materials which may be useful alternatives to the widely used $\mathrm{U}\left[\mathrm{N}\left(\mathrm{SiMe}_{3}\right)_{2}\right]_{3} \cdot{ }^{28,29}$
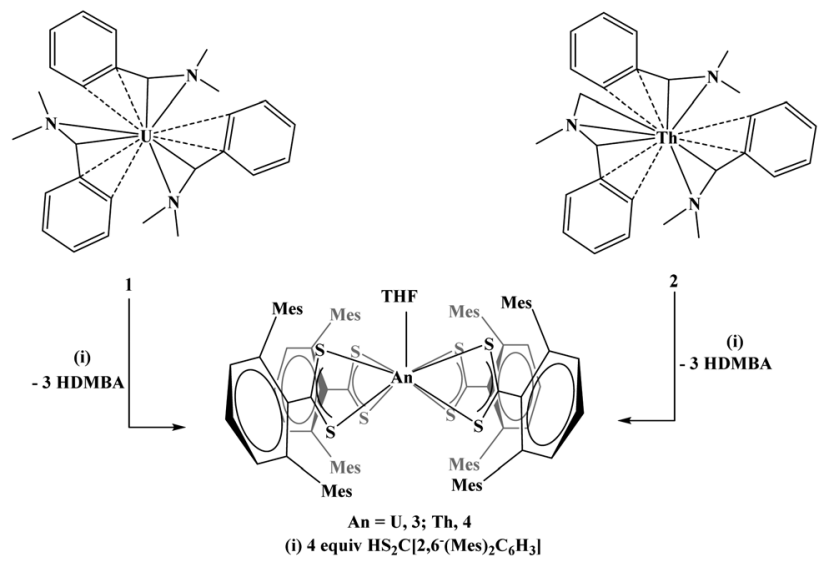

The average U-S bond distances in 3 of 2.8775(17) A are longer than those seen in $\left[\mathrm{U}(\mathrm{dddt})_{3}\right]^{2-}$, which range from $2.717-2.760 \AA$. This increase is attributed to the greater steric properties of the terphenyl-based ligand. The average Th-S bond distances in 4 of

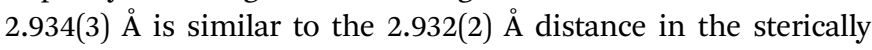
crowded dithiophosphinate complex $\mathrm{Th}\left(\mathrm{S}_{2} \mathrm{P}^{t} \mathrm{Bu}_{2}\right)_{4}$. These distances are significantly longer than the 2.9075(5) $\AA$ and 2.911(4) ̊̊ distances in the less crowded complexes $\operatorname{Th}\left(\mathrm{S}_{2} \mathrm{P}^{\mathrm{i}} \mathrm{Pr}_{2}\right)_{4}{ }^{30}$ and $\operatorname{Th}\left[\mathrm{S}_{2} \mathrm{P}\left(\mathrm{C}_{6} \mathrm{H}_{11}\right)_{2}\right]_{4}{ }^{31}$ respectively. The difference in bond distances of 3 and $4(\sim 0.057 \AA)$ is consistent with the Shannon radii of nine-coordinate $\mathrm{U}^{4+}(1.19 \AA)$ vs. $\operatorname{Th}^{4+}(1.23 \AA) .{ }^{32}$

In summary, using the potassium salt of dimethylbenzylamine, we have synthesized and characterized a rare U(III) alkyl complex. When the analogous reaction is attempted with a uranium(Iv) starting material, ligand coupling is observed along with reduction to $\mathrm{U}(\mathrm{III})$. The thorium complex featured $\mathrm{C}-\mathrm{H}$ bond activation of one of the methyls on the dimethylamine group. The synthetic utility of these complexes was evaluated using a sterically demanding dithiocarboxylate ligand, $\mathrm{HS}_{2} \mathrm{C}\left(\mathrm{C}_{6} \mathrm{H}_{3} \mathrm{Mes}_{2}\right)$, which produced analogous products, $\mathrm{An}\left[\mathrm{S}_{2} \mathrm{C}\left(2,6-(\mathrm{Mes})_{2} \mathrm{C}_{6} \mathrm{H}_{3}\right)\right]_{4}(\mathrm{THF}), \mathrm{An}=\mathrm{U}$; Th. Further reactivity is currently under investigation.
We gratefully acknowledge the Department of Energy, Office of Science Early Career Research Program under Award DE-SC0014174 (JRW). WWL was supported by the U.S. Department of Energy, Office of Science, Basic Energy Sciences, Chemical Sciences, Biosciences, and Geosciences Division (CSGB), Heavy Element Chemistry Program and was performed at Lawrence Berkeley National Laboratory under contract No. DE-AC02-05CH11231.

\section{Notes and references}

1 L. A. Seaman, J. R. Walensky, G. Wu and T. W. Hayton, Inorg. Chem., 2013, 52, 3556-3564.

2 S. Fortier, B. C. Melot, G. Wu and T. W. Hayton, J. Am. Chem. Soc., 2009, 131, 15512-15521.

3 S. Fortier, J. R. Walensky, G. Wu and T. W. Hayton, J. Am. Chem. Soc., 2011, 133, 11732-11743.

4 E. A. Pedrick, P. Hrobarik, L. A. Seaman, G. Wu and T. W. Hayton, Chem. Commun., 2016, 52, 689-692.

5 S. J. Kraft, P. E. Fanwick and S. C. Bart, J. Am. Chem. Soc., 2012, 134, 6160-6168.

6 S. A. Johnson, J. J. Kiernicki, P. E. Fanwick and S. C. Bart, Organometallics, 2015, 34, 2889-2895.

7 J. M. Manriquez, P. J. Fagan, T. J. Marks, S. H. Vollmer, C. S. Day and V. W. Day, J. Am. Chem. Soc., 1979, 101, 5075-5078.

8 W. G. Van der Sluys, C. J. Burns and A. P. Sattelberger, Organometallics, 1989, 8, 855-857.

9 S. Di Bella, G. Lanza, I. L. Fragalà and T. J. Marks, Organometallics, 1996, 15, 205-208.

10 E. M. Matson, W. P. Forrest, P. E. Fanwick and S. C. Bart, J. Am. Chem. Soc., 2011, 133, 4948-4954.

11 P. G. Edwards, R. A. Andersen and A. Zalkin, Organometallics, 1984, 3, 293-298.

12 L. A. Seaman, E. A. Pedrick, T. Tsuchiya, G. Wu, E. Jakubikova and T. W. Hayton, Angew. Chem., Int. Ed., 2013, 52, 10589-10592.

13 E. A. Pedrick, L. A. Seaman, J. C. Scott, L. Griego, G. Wu and T. W. Hayton, Organometallics, 2016, 35, 494-502.

14 F. T. Oakes and J. F. Sebastian, J. Organomet. Chem., 1978, 159, 363-371.

15 A. C. Behrle and J. A. R. Schmidt, Organometallics, 2011, 30, 3915-3918.

16 T. V. Lubben, K. Ploessl, J. R. Norton, M. M. Miller and O. P. Anderson, Organometallics, 1992, 11, 122-127.

17 M. Roger, T. Arliguie, P. Thuéry, M. Fourmigué and M. Ephritikhine, Inorg. Chem., 2005, 44, 594-600.

18 F. Moro, D. P. Mills, S. T. Liddle and J. van Slageren, Angew. Chem., Int. Ed., 2013, 52, 3430-3433.

19 K. R. Meihaus, J. D. Rinehart and J. R. Long, Inorg. Chem., 2011, 50, 8484-8489.

20 J. D. Rinehart and J. R. Long, J. Am. Chem. Soc., 2009, 131, 12558-12559.

21 F. Ortu, A. Formanuik, J. R. Innes and D. P. Mills, Dalton Trans., 2016, 45, 7537-7549.

22 W. J. Evans, J. R. Walensky and J. W. Ziller, Chem. - Eur. J., 2009, 15, 12204-12207.

23 N. A. Siladke, C. L. Webster, J. R. Walensky, M. K. Takase, J. W. Ziller, D. J. Grant, L. Gagliardi and W. J. Evans, Organometallics, 2013, 32, 6522-6531.

24 K. C. Jantunen, C. J. Burns, I. Castro-Rodriguez, R. E. Da Re, J. T. Golden, D. E. Morris, B. L. Scott, F. L. Taw and J. L. Kiplinger, Organometallics, 2004, 23, 4682-4692.

25 D. Brown, D. G. Holah and C. E. F. Rickard, J. Chem. Soc. A, 1970, 423-425.

26 J. A. Macor, J. L. Brown, J. N. Cross, S. R. Daly, A. J. Gaunt, G. S. Girolami, M. T. Janicke, S. A. Kozimor, M. P. Neu, A. C. Olson, S. D. Reilly and B. L. Scott, Dalton Trans., 2015, 44, 18923-18936.

27 D. L. Clark, M. M. Miller and J. G. Watkin, Inorg. Chem., 1993, 32, 772. 28 R. A. Andersen, Inorg. Chem., 1979, 18, 1507-1509.

29 R. J. Baker, Coord. Chem. Rev., 2012, 256, 2843-2871.

30 A. C. Behrle, A. Kerridge and J. R. Walensky, Inorg. Chem., 2015, 54, 11625-11636.

31 A. A. Pinkerton, A. E. Storey and J.-M. Zellweger, J. Chem. Soc., Dalton Trans., 1981, 1475-1480.

32 R. Shannon, Acta Crystallogr., Sect. A: Cryst. Phys., Diffr., Theor. Gen. Crystallogr., 1976, 32, 751-767. 